Summer 2009

\title{
On the Constitutionability of Global Public Policy Networks
}

Petra Dobner

Martin Luther University Halle-Wittenberg

Follow this and additional works at: https://www.repository.law.indiana.edu/ijgls

Part of the Constitutional Law Commons, and the International Law Commons

\section{Recommended Citation}

Dobner, Petra (2009) "On the Constitutionability of Global Public Policy Networks," Indiana Journal of Global Legal Studies: Vol. 16 : Iss. 2 , Article 10.

Available at: https://www.repository.law.indiana.edu/ijgls/vol16/iss2/10

This Symposium is brought to you for free and open access by the Law School Journals at Digital Repository @ Maurer Law. It has been accepted for inclusion in Indiana Journal of Global Legal Studies by an authorized editor of Digital Repository @ Maurer Law. For more information, please contact rvaughan@indiana.edu.

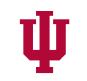

JEROME HALL LAW LIBRARY

$$
\begin{aligned}
& \text { INDIANA UNIVERSITY } \\
& \text { Maurer School of Law }
\end{aligned}
$$

Maurer School of Law
Blooming tou 


\title{
On the Constitutionability of Global Public Policy Networks
}

\author{
Petra Dobner*
}

\begin{abstract}
Global Public Policy Networks (GPPNs) are increasingly influential in the global policy-making process. According to the Global Public Policy Institute, GPPNs are cross-sectoral coalitions of actors from governments, international organizations, civil society, and private industry. In structure, these networks differ from traditional hierarchical organizations, but their primary functions-negotiation, coordination, rulemaking, and implementation-pick up the classic tasks of formal international organizations and intergovernmental cooperation.

The power and acceptance of these networks are based on the real or alleged expertise of their members, their former or current formal positions in national or international organizations or private industry, and their personal connections. Although these features nourish the assumption that GPPNs are efficient problemsolvers, there is no empirical proof of this belief. Potential sources of their legitimacy await grounding in a solid normative theory. Efficiency cannot be considered a ready substitute for the formal democratic legitimacy that these networks are lacking in either empirical or theoretical regard. The phenomenon of GPPNs, therefore, touches some core problems of the global constitutionalism project - the idea of subjecting transnational, non-state actors to the rule of a global constitutional agreement.

As powerful actors in the transnational sphere, GPPNs must address three challenges relating to the future of constitutionalism. First, is it possible to put non-state political actors under a constitutional regime? Second, if it is possible, how does one do so? Third, in what ways can the project of constitutionalism be expanded beyond the

* Political Scientist, Martin Luther University Halle-Wittenberg, Germany. This article has profited very much from discussions with the focus group on "Constitution Beyond the Nation State" at the Wissenschaftskolleg Berlin. I am grateful to Dieter Grimm, Bogdan Iancu, Martin Loughlin, Fritz W. Scharpf, Alexander Somek, Gunther Teubner, and Rainer Wahl.
\end{abstract}

Indiana Journal of Global Legal Studies Vol. $16 \# 2$ (Summer 2009)

CIndiana University Maurer School of Law - Bloomington 
frame of the nation-state, if at all? The answers to these questions must address the central problem of global constitutionalism: how the traditional bond between the nation-state and its constitution can be dissolved without abandoning the accomplishments that the project of the modern state constitution stands for-founding, legitimizing, and confining democratic governance.

\section{INTRODUCTION}

Non-state actors in general, and networks in particular, play a growing role in the global policy-making process. Within the wide and rather diffuse array of actors falling into this category, Global Public Policy Networks (GPPNs) are the most ambitious successors of the state as the primary actor in the international realm.

GPPNs may be described as multi-sectoral networks comprised of actors from civil society, governmental agencies, and industry. Their range of activities covers all stages of the policy process. In addition to agenda-setting, they take part in policy formulation, negotiation and rule-making, coordination and implementation, and evaluation. ${ }^{1}$ More than other types of transnational networks (epistemic communities ${ }^{2}$ or transnational advocacy coalitions, for example), ${ }^{3}$ GPPNs indicate a shift from government to governance.

Private enterprise in politics, especially for GPPNs, is welcomed on the assumption that it provides better knowledge of the problem at hand, increases efficiency and effectiveness of outcomes, and facilitates a wider representation of stakeholders. However, these assumptions are premature given that the empirical and theoretical knowledge available about the forms and interests of private participation in transnational politics in general, and networks in particular, does not yet provide a suffcient basis to allow for substantial generalizations about these political actors. ${ }^{4}$

1. Thorsten Benner et al., Global Public Policy: Chancen und Herausforderungen des vernetzten Regierens, 48 Zeitschrift für Politık 361, 364-66 (2001); Diane Stone, The "Policy Research" Knowledge Elite and Global Policy Processes, in Non-State Actors in World Politics 113 (Daphné Josselin \& William Wallace eds., 2001).

2. Peter M. Haas, Introduction: Epistemic Communities and International Policy Coordination, 46 Inr'l Org. 1 (1992); Peter M. Haas, Conclusion: Epistemic Communities, World Order, and the Creation of a Reflective Research Program, 46 INT'L ORG. 367 (1992).

3. Margaret E. Keck \& Kathryn Sikgink, Activists Beyond Borders: Advocacy Networks in International Politics (1998).

4. Daphné Josselin \& William Wallace, Non-State Actors in World Politics: A Framework, in Non-State Actors in World Politics, supra note 1, at 1, 14. 
Moreover, the readiness to make up for lack of input legitimacy by increasing output legitimacy is neither empirically nor theoretically supported. ${ }^{5}$

The question of the legitimacy and accountability of GPPNs is, therefore, especially crucial for the project of democratizing global politics. The theoretical and practical challenges associated with this project are addressed in this paper. The framework offered is an attempt to extend the idea of constitutionalism beyond the nation-state.

Unfortunately, "transnational constitutionalism" is marked by similar uncertainties. The dissociation of "constitution" and "state" opens a wide space for redefining the substance of constitutionalism. A core decision must be made about the minimal normative premises required before the label "constitutional" can be applied. Should the term "constitution" be reserved for higher law, does the constitution fulfill certain normative imperatives? Or should we understand a constitution as an expression of a political being? Neither alternative is completely convincing. While the first case holds up high standards, it is unlikely that we will find a constitution in the transnational sphere under these premises, and our legal and normative reasoning may fail to recognize even the existence of private actors in the field. ${ }^{6}$ If, on the other hand, constitutions are stripped of normative foundations, the world beyond states abounds with constitutional options. The critical and desirable distance between constitutional design and political reality, however, then diminishes to zero, and the label of constitutionalism becomes meaningless.

Whether GPPNs are legitimate constitutionally, therefore, depends on two issues demanding clarification. Empirically, we need to know more about the character of the networks under discussion, and theoretically, we have to make a well-grounded decision about what ought to be called constitutionalism or constitutionalization in the transnational realm.

This set of problems will be dealt with in four steps. First, after some introductory notes on GPPNs, I will bring forward some arguments indicating why GPPNs should be constitutionalized. Second, I will outline why, if we hold on to a full understanding of the "modern constitution" developed in the context of the nationstate, GPPNs cannot be constitutionalized. Third, I will explain why expanding our understanding of constitutionalism to include an incremental process of societal

5. Robert O. Keohane \& Joseph S. Nye, The Club Model of Multilateral Cooperation and Problems of Democratic Legitimacy, in Efficiency, Equity, Legitimacy: The Multilateral Trading System at the Millennium 264, 272, 282 (Roger B. Porter et al. eds., 2001).

6. A. Claire Cutler, Private Regimes and Interfirm Cooperation, in The Emergence of Private Authority in Global Governance 23, 24 (Rodney Bruce Hall \& Thomas J. Biersteker eds., 2002). 
self-constitutionalization does not cure our problem. Finally, I will suggest some research questions that need to be answered in order to overcome this impasse.

\section{GPPNs and Constitutions}

GPPNs are new collective actors in the transnational policy arena. They are characterized by the multinational and cross-sectoral provenance of their participants (governmental and international organizations, businesses, and civil society), who work together in a defined policy field with the aim to devise globally relevant policy matters. Existing GPPNs include the World Commission on Dams, the Global Water Partnership, the Medicines for Malaria Venture, and the Clean Development Mechanism for the implementation of the Kyoto Protocol.?

The promotion of GPPNs is generally supported on the assumptions that the technical complexities of late modernity extend beyond the capacities of governments and international organizations; that a better representation of otherwise marginalized groups, especially from the south, can be achieved by direct participation of civil society; and that the networks will produce better policy results and have a higher rate of efficiency in problem-solving. ${ }^{8}$ Central to these arguments is the claim that GPPNs possess political capacities that traditional state agencies do not, including: (1) that the participants' multiplicity of origins generates a wider knowledge base than traditional governmental agencies; (2) that the inclusion of partners from related businesses increases efficiency in problem-solving; (3) that civil society actors inform the network about needs and help implement policy more effectively; and (4) that governments and international organizations take part in the network in order to find support in fulfilling their traditional tasks of regulating affairs of common interest.

The background of these assumptions consists of facts, aspirations, and ascriptions that, combined, suggest that public-private partnerships are a remedy for the failures of governmental politics. The standard argument sees globalization, technical innovation, and ecological conditions as creators of global problems for which solutions can only be found beyond both state and international organizations. It seems obvious, then, that the broad scale and urgency of those problems require

7. Thorsten Benner et al., Global Public Policy Networks: Lessons Learned and Challenges Ahead, Brook ings Rev., Spring 2003, at 18.

8. The Secretary-General, Report of the Secretary-General on Enhanced Cooperation Between the United Nations and All Relevant Partners, in Particular the Private Sector, II 6, delivered to the General Assembly, U.N. Doc. A/62/341 (Sept. 14, 2007) [hereinafter Enhanced Cooperation]; Benner, supra note 1 . 
political actors who themselves transcend the limited borders of a state-centered world. Closer scrutiny, however, shows that the growing awareness of truly global problems did not simultaneously lead to shrinking of the importance of intergovernmental cooperation or of the state itself. In fact, the first United Nations Conference on the Human Environment in Stockholm in 1972 maintained that states were primarily responsible for providing solutions to global problems. ${ }^{9}$ The environmental debate continued until the beginning of the 1990s, when market ideology, refreshed after the end of the Cold War, suggested that private action should cure what appeared to be failures of public institutions. In this scenario, the call for more responsibility by private actors and closer cooperation between actors from different sectors reflects, above all, the damaged reputation of representative government, the state, and the world of international cooperation among governmental agencies. While this should not be misunderstood as a denial of state failure, it still should be taken seriously that the privatization of politics is due less to a clear analysis of its potential benefits and risks, and more to a turning point in the longstanding controversy about the particular merits of "state" or "market."

Moreover, the arguments in favor of GPPNs may be questioned on theoretical as well as empirical grounds. ${ }^{10}$ From a normative perspective, "participation" cannot be counted as a substitute for direct or representative democracy by which the basic rule of equal representation for everyone is fully translated into practical procedures of decision-making. Often participation is presented as "more democratic" than intergovernmental procedures. Yet practically, participation may easily be restricted to those who are welcomed to participate by the organizing elites and to those who can afford it. The wisdom and interests of those who organize the network, not the equal representation of all stakeholders, guard the entrance to the decision-making process. Participation, therefore, has little to do with democracy. At best it is a mode of broadening the arena of decision-makers or information gatherers, and at worst, it is simply a veil shrouding the decisions of a small number of global elite.

Although the inclusion of civil society and private business indeed may provide relevant knowledge for policymakers, it is politically naive to take for granted that they act in the name of the common good if they play a dominant role in

9. See United Nations Conference on the Human Environment, June 5-16, 1972, Declaration of the U.N. Conference on the Human Environment, art. 2, princ. 7, U.N. Doc. A/CONF.48/14/Rev. 1 (Nov. 1973); see also United Nations Conference on the Human Environment, June 5-16, 1972, Action Plan for the Human Environment, 111 6-27, U.N. Doc. A/CONF.48/14/Rev. 1 (Nov. 1973).

10. Petra Dobner, Nur zweite Reihe? - Staat und Regierung in der Global Governance of Water, in Führen Regierungen Tatsächlich? Zur Praxis gouvernementalen Handelns 155 (Everhard Holtmann \& Werner J. Patzelt eds., 2008). 
decision- or rule-making. Civil society is not always benign; it does not necessarily constitute the better part of a society as opposed to the "bad" state. Skepticism is even greater when it comes to private business. From Marx to Friedman, we are informed that industry is about profits, not about realizing general interests. This is a major reason why Adam Smith warned sharply against letting market actors decide upon public matters."

It remains to be empirically proven whether the efficiency in a policy arena really increases when GPPNs are involved. So far as my own empirical research on Global Water Partnership and associated networks in the Global Water Politics is concerned, there is no proof. ${ }^{12}$ The involvement of GPPNs in this sector enhanced neither the quality of the policy process, nor the results. While it cannot be concluded that this holds true for all GPPNs, it nevertheless casts doubt on the generalized vision that GPPNs are a powerful new instrument in tackling mankind's most pressing problems.

Further research is needed before the new modes of governance can be called a substantial alternative to intergovernmental action. Until then, maintaining more efficient transnational networks in order to solve global problems remains a matter of hope, not analysis. Nonetheless, GPPNs play an important role in shaping transnational politics and in creating a transnational polity. GPPNs are being actively built based on their reputation of enhancing the quality of politics in matters that are important, if not essential. Accordingly, the quest for their constitutionability is rooted in the fact that they exercise political power by dealing with matters traditionally resting with the state.

The reasoning behind the basic tasks of constitutions supports this demand. As clearly pointed out by Dieter Grimm, the modern constitution aims at the comprehensive coverage of all matters, the inclusion of all citizens, and the democratic legitimization, not only limitation, of the rulers. ${ }^{13}$ Among the different functions of a modern constitution, the ability to submit political power to higher law is an especially important feature. Constitutionalization in this respect is the promise to integrate the exercise of political power in a democratic setting in

11. Adam Smith, 1 An Inquiry into the Nature and Causes of the Wealth of Nations 264 (5th ed. 1904).

12. Petra Dobner, Did the State Fail? Zur Transnationalisierung und Privatisierung der öffentlichen Daseinsfürsorge: Die Reform der globalen Trinkwasserpolitik, in StaAt und Gesellschaftfähig zur Reform? 247 (Klaus Dieter Wolf ed., 2007).

13. Dieter Grimm, Deutsche Ver fassuncsgeschichte 1776-1866, at 12 (1988); Dieter Grimm, Die Verfassung im Prozess der Entstaatlichung, in Der Stant des Grundgesetzes-Kontinuitüt und WANDEL 145 (Michael Brenner et al. eds., 2004) [hereinafter Grimm, Entstaatlichung]. 
which formal procedures of decision-making (including control mechanisms), as well as the formalized and democratic election of the political staff, are necessary prerequisites for the determination of political goals and the formulation and implementation of political decisions. ${ }^{14}$ Ideally, then, a constitution links input and output legitimacy and guarantees that all important matters in a given political entity are given consideration by a political body that enjoys at least the supportive tolerance of all who are concerned by the outcomes in its territory.

On this basis, the constitutionalization of GPPNs can easily be postulated. First, the networks deal with matters of unquestioned importance. Their participation in these processes is not restricted to proposing measures or lobbying. Instead, GPPNs are present, and often dominant, in all stages of the policy cycle. Second, while GPPNs are currently active in only certain fields, their influence is likely to become more extensive in the future. ${ }^{15}$ Third, GPPNs substitute for national governments in their traditional assignment of dealing with matters of general interest. ${ }^{16}$ Last but not least, by shaping transnational politics, GPPNs also take part in the creation of a transnational polity.

All in all, GPPNs are gaining responsibility for matters of global importance in the transnational realm. Yet the effects of their work are not restricted to the transnational space, but also shape and influence the domestic sphere. In both respects they create a political arena that was traditionally under the guidance of domestic constitutional rule. The postulation that they should be subjected to constitutional restraints is therefore apparent if one adheres to the well-established conviction that the exercise of power should be regulated, legitimized, and democratized by means of a constitution.

\section{Why GPPNs Cannot be Constitutionalized}

Constitutionalization requires a subject that is not only in need of a constitution (konstitutionsbedürftig), but constitutionable (konstitutionsfähig). Unfortunately, the demand to constitutionalize GPPNs is not mirrored by their capability for constitutionalization.

A significant feature of constitutionalism is the constitution's ability to formalize the life of a political entity by means of higher rules. Moreover, constitu-

14. ERnst Fraenkel, Die repräsentative Und die Plebiszitäre Kompon ente im demokratischen Verfassungsstaat (1991).

15. See Enhanced Cooperation, supra note 8.

16. Dobner, supra note 10. 
tional rules are not as easily changed as others. They are durable and therefore arouse the expectation of stability and continuance. In contrast, networks derive their specific productivity from the informality and flexibility of the entrance rules, as well as how the work in the network is conducted. ${ }^{17}$ In comparison to traditional state structures, networks have the advantage of including only those who are considered important-or important to those who set the goals of the network - and dealing with subjects on a personal or horizontal level, leaving aside all questions of equal representation and formalized procedures. Constitutionalizing GPPNs, therefore, finds a first limit in their structural opposition to long-standing procedural rules about their ways and means.

Network analysis was already confronted with the problem of the multiplicity and diversity of networks in the national context. Analyzing policy networks meant investing intensive labor into understanding a given network at the time of the initial analysis. This only allowed speculative extrapolations from other networks and prohibited analyzing the network at some other point of its existence. In short, network analysis is momentary. Generalizations are thus limited to the description of general features of networks, which is usually done by juxtaposing them with the opposing governance forms of market and hierarchy.

The problem of an analytical comprehension of networks grows with the proliferation of additional transnational networks, one reason why transnational networks are far less explored than national networks. There are two main reasons for this lack of exploration: (1) transnational networks include members from different states and often different sectors, and therefore investigation of the network becomes far more complex and costly, and (2) while domestic networks are usually built on the experience of shared needs, a transnational network can be established for quite different reasons, such as pushing an agenda or implementing a policy in which none of the participants is directly involved. As is commonly supposed for domestic networks, bargaining between actors who are mutually interested in the other actors' participation is not necessarily the dominant mode of conduct in transnational networks. Network action and network goals of single members or the network as a whole, therefore, cannot be distilled from the personal or corporate interests of their members.

Intrastate network results ultimately have to be endorsed by an elected political body if they are to become national policies. The state polity functions as a rationalizing force in the discussion of possible network goals. ${ }^{18}$ In the transna-

17. Anne Mette KJer, Governance 199 (2004).

18. Dobner, supra note 10. 
tional sphere, there is no ultima ratio of a binding polity, so unconfined power processes are much more likely.

In general, the differences between domestic and transnational networks not only multiply the problems of scientific investigation of transnational networks, but also limit their constitutionability. Constitutionalizing institutions requires profound knowledge about the institutions' real and possible structures. How can they function? What can they achieve? How can they be controlled? How are their members elected? What can be done if procedures fail? Constitutions are imagined institutions that grow into a reality from the constant iteration from the crib of a text. So far as networks are concerned, we have neither the knowledge of how they really work, nor an elaborate idea of how they should work. How, then, could they be constitutionalized?

There are two further prerequisites for constitutionalized states that are not only inapplicable to transnational networks, but are also explicitly abandoned. These include the concentration of power in the state and the division between public and private. ${ }^{19}$ Both are essential for the erection of a legal superstructure guiding politics because only under these circumstances can the encompassing rule of law be established. In the national arena, this split was called into question by the corporate state. The integration of private actors erodes both divisions on the international plane even more. ${ }^{20}$ For these reasons it is unlikely, if not impossible, to transfer the idea of modern constitutions to public-private actor networks beyond the state.

\section{Expanding the Idea of Constitutionalism-A Cure?}

If GPPNs should be constitutionalized, but are not adaptable to the standards of the modern state constitution, should we not alter the idea of what a constitution necessarily must contain?

The most ambitious project in this direction is the idea of "societal constitutionalism." 21 According to Gunther Teubner, today's "constitutional ques-

19. Grimm, Entstaatlichung, supra note 13, at 154.

20. Anne Peters, Global Constitutionalism in a Nutshell, in Weltinnenrecht 535, 544 (Klaus Dicke et al. eds., 2005).

21. See, e.g., David Sciulli, Corporate Power in Civil Society: An Application of Societal Constitutionalism (2001); David Sciulli, The Theory of Societal Constitutionalism: Foundarions of a Non-MarXist Critical Theory (1991); Gunther Teubner, Breaking Frames: Economic Globalisation and the Emengence of lex mercatoria, 5 Eur. J. Soc. THEORY 199, 208-09 (2002); Gunther Teubner, Die anonyme Matrix: Zu Menschenrechtsverletzungen durch "private" transnationale Akteure, 44 Der Stant: Zeitschrift für Staatslehre und Verfassungsgeschichte, deutsches und europäis- 
tion" is how constitutional theory is "to respond to the challenge arising from the three current major trends-digitisation, privatisation and globalization ..."22 The basic answer is a radical departure from the state-centrist approach of taking the world system seriously and instead identifying society as the primary source for the constitutional future. Teubner's argument advocates for the emergence of a multiplicity of civil constitutions: ${ }^{23}$

The constitution of world society comes about not exclusively in the representative institutions of international politics, nor can it take place in a unitary global constitution overlying all areas of society, but emerges incrementally in the constitutionalisation of a multiplicity of autonomous subsystems of world society. ${ }^{24}$

There is no longer hope for legal unity, based on the observation of the fragmentation of the legal world as an epiphenomenon of the multidimensional fragmentation of world society. ${ }^{25}$ In light of societal constitutionalism, attempts to embed the emerging world of transnational networks in the discourse of state-centered constitutionalism (like other attempts to conceptualize a universal global constitution) therefore have to be "reproached with not generalising the traditional concept of the constitution sufficiently for today's circumstances, nor re-specifying it carefully enough, but instead uncritically transferring nation-state circumstances to world society. ${ }^{26}$ Rather, one should recognize that legal orders are plural, and that they emerge not from the centers, but from the periphery of law.

If it is true that the dominant sources of global law are now to be found at the peripheries of law, at the boundaries with other sectors of world society, not any longer in the existing centres of law-makingnational parliaments, global legislative institutions and intergovern-

Ches ÖfFentliches Recht 161 (2006); Gunther Teubner, Societal Constitutionalism: Alternatives to State-centred Constitutional Theory (Storrs Lecture at Yale Law School, Oct. 7, 2003), http://www. jura.uni-frankfurt.de/ifawzl/teubner/dokumente/societal_constitutionalism.pdf [hereinafter Teubner, Societal Constitutionalism].

22. Teubner, Societal Constitutionalism, supra note 21 , at 2.

23. Id. at 5 .

24. Id.

25. Andreas Fischer-Lescano \& Gunther Teubner, Fragmentierung des Weltrechts: Vernetzung globaler Regimes statt etatistischer Rechtseinheit, in WeLtSTAat Und WeLtstaATlichKeIT: Beobachtungen globaler politischer Strukturbildung 37 (Mathias Albert \& Rudolf Stichweh eds., 2007).

26. Teubner, Societal Constitutionalism, supra note 21 , at 3. 
mental agreements-then this at the same time means that norms of constitutional quality are always also being produced there. ${ }^{27}$

Constitutionalizing the world, in this view, develops from "underground evolutionary processes of long duration in which the juridification of social sectors also incrementally develops constitutional norms." ${ }^{28}$

In some respects, the idea of societal constitutionalism is very appealing. More than other approaches, it radically departs from the idea of the state as the center of legal norms and as the main container of political power. The approach finds evidence in an existing legal pluralism, in transnational sectoral legal regimes like the lex mercatoria, and in the fact that the state is not the only actor on the global scene. It also takes seriously that the public-private split is as blurred as the division between the domestic and international arenas of politics. Most important is its attempt to reformulate the constitutional question for the twenty-first century by asking how constitutionalism will address the problems of digitization, privatization, and globalization.

However, one crucial problem remains unaddressed. Constitutionalization in the nation-state did not leave open how a state and a society should deal with the main challenge of organizing the ability to act collectively. It was an answer to unavoidable normative demands: that this ability to act should rest on the equal representation of everybody in the decision-making process, that the exercise of power should be grounded (and not only pictured) in the constitution, and that the constitution should define a political body, not just describe it.

It would be short-sighted to reject these objections as state-centered or oldfashioned. The constitutional linkage between these normative democratic demands and the practical organization of the policy process is essential for meeting the simultaneous demands of achieving a collective capability to act and allowing individual freedom. It cannot simply be removed from constitutional thought without giving up on basic requirements of human dignity. Rather, one should take Teubner at his own word when he rightly asks: "[W]ill constitutional theory manage to generalise its nation-state tradition in contemporary terms and respecify it? Can we, then, make the tradition of the nation-state constitution fruitful, while at the same time changing it to let it do justice to the new phenomena of digitisation, privatisation and globalisation?" ${ }^{29}$ Surely it would not do any justice

27. Id. at 13-14.

28. Id. at 14.

29. Id. at 2. 
to the "tradition of the nation-state constitution" to simply drop its normative qualities as something of minor importance.

The real extent of the problem, therefore, comes into view only if the constitutional question is completed. How can the traditional bond between the nation-state and its constitution be dissolved without abandoning the accomplishments which the project of the modern state constitution also stands for-founding, legitimizing, and confining democratic governance? In light of this question, the project of societal constitutionalism reveals some shortcomings that need to be addressed.

Societal constitutionalism builds on the world as it is. It cannot (and should not) be denied that transnational regulations exist and that they emerge from societal action. The claim that this should be called "constitutionalism," though, is only possible by abandoning the normative meanings that differentiate a constitution in the nation-state from self-regulation or other rules. Why, then, should self-regulation in the world system be "constitutional?" Within societal constitutionalism, "every process of juridification ... contains latent constitutional normings." 30 "Not every polity has a written constitution, but every polity has constitutional norms. These norms must at least constitute the main actors, and contain certain procedural rules. Theoretically, a constitution could content itself with setting up one law-making organ, and regulating how that organ is to decide the laws." ${ }^{31}$ Teubner concludes that any emergence of a legal system establishes the constitutional quality. ${ }^{32}$ But this argument presupposes a given "polity," and the world system does not. To put it differently, one might follow Uerpmann in his direction of the argument that if there is a polity, then this polity is built on at least some minimal constitutional norms (main actors and procedural rules), which theoretically could be set up by one lawmaking organ. But in the argument of societal constitutionalism, the order is reversed. If there is one law-making organ, which establishes procedural rules for the main actors, then there is "constitutional quality." Teubner's statement, that there is constitutional quality in any kind of law production, has a significantly different meaning from saying that a polity rests on constitutional norms, written or unwritten. The constitutional quality of any form of law-making remains undetermined. There is no world polity, so the basis of the argument is absent.

The constitutional quality of societal self-regulation must also be called into question for another reason. The modern constitution came into being because it

30. Id. at 12 .

31. Id. at 12 (quoting Robert Uerpmann, Internationales Verfassungsrecht, 56 JURISTENzEITUNG 565, 566 (2001)).

32. Id. at 12 . 
could fulfill the secular need to find and limit power relations. Constitutionalization must achieve more than self-organization within a particular field of interest for those who have a stake in that field. It lays the foundation of a political entity by subjecting the potential hierarchies to rules of entrance and co-determination of all people. If it is reduced to self-regulation in certain fields, it falls back to partial regulations for some, leaving the question of the hierarchical orders of different systems of rule unresolved. In contrast, it was a central achievement of the modern constitution to overcome the multiplicity and ambiguity of several layers of legal norms. By finding explicit rules for who should decide upon what, legal hierarchy was a necessity for taming political power. Self-regulation cannot stand up to this achievement.

A final doubt about the practicality of societal constitutionalism stems from the notion of a free society regulating itself. As attractive as the idea of societal self-regulation may be, it ignores the fact that the democratic state was not established in contrast to society in the first place, but as a means for society to organize itself politically. Especially in light of functional differentiation, it is implausible to believe that the political system is reintegrated into the whole of society. It is much more likely to assume that some other functional differentiation takes place that does not substitute society for the state, but rather cross-sectoral elites whose accountability to everybody may very well be called into question.

For different reasons than the modern constitution, yet with the same result, the idea of societal constitutionalism falls short of solving a central problem of globalized politics-how can private global actors who play a dominant role in the organization of common interests be subjected to the rule of higher law?

\section{Overcoming the Impasse? Research Proposals}

We have now sketched the problem: either we hold constitutional ideals high, and accept that the chances for constitutionalism in world politics are very low, or we agree to identify constitutional quality in every area of law production, and accept that the value of constitutionalization will be called into question. Some suggestions for a review of our contemporary reasoning about constitutionalism and the inclusion of global non-state actors can be derived from the impasse this article presents.

The first picks up on Teubner's starting point. It is right to ask, "what is the constitutional question of today?" As pointed out, this question must include two basic elements: a description of the current main trends in global politics and a 
statement about the distinctive features of constitutionalism for the benefit of giving the term a substantial and distinct meaning.

In contrast to Teubner, however, I believe that we are incorrect to omit the state as a relevant factor. Most discussions on the state's future in the past few years reach the conclusion that the state remains relevant and that, although its monopolist position is threatened, the state nevertheless remains integrated in the global system and will play an important role in the foreseeable future. If this is true, constitutionalism will have to be thought of not only as something that exists in the state in the old sense, but also as something that might be extended or transferred to the global arena. The constitutional question, then, will have to address both the future of constitutionalism within the state, and the possible future of constitutionalization beyond it. New questions arise from here: what are the linkages between them going to look like? How could the tasks for state and transnational constitutions be divided? Is their relation going to be hierarchical or heterarchical? And in what respect?

A second field of research evolves from observations on hierarchy and networks. As pointed out by network analysis, there is good reason to believe that networks cannot work alone, but instead must rely on hierarchical structures:
When the benefits or costs of a particular policy are highly concen- trated, network steering may fail to take account of the aggregated interests and instead be highly skewed towards a few powerful in- terests. Governance processes cannot, therefore, rely entirely on networks; they have to draw upon hierarchic structures as well. ${ }^{33}$

It follows not only that we need to know more about workable and desirable combinations of hierarchical and horizontal steering mechanisms, but that we must rethink the readiness to dissolve government into governance, and undertake a renewed exploration of the future of representative government.

Teubner's description of the main challenges to constitutionalism touches a third field for further investigation: while one can agree that privatization, digitization and globalization are main trends, they diverge in their inevitability and specific form. The so-called "anti-globalist" movement clearly shows that different ideas about what globalization could look like are possible. If globalization continues to be mostly neoliberal, the constitutional question will be very different than it would be in any form of democratized globalization.

33. KJER, supra note 17 , at 58. 
The same is true if one thinks about the challenges of privatization. Privatization is not an inevitable take-over; it is a chosen option about how global and domestic politics can be conducted. Shaping and regulating private action is, for many parts of the political process, not only possible, but a matter of fact. The inclusion of private actors takes place under the responsibility and guidance of genuine political actors. The constitutional question, therefore, is highly dependent on a political question that has to be answered: how should private action in politics be integrated?

Another set of problems is associated with power structures. Network and policy analyses in the domestic sphere were conducted in the spirit of an "endogenous democracy." It was simply taken for granted that the improvement of the policy process was guided by an unquestioned democratic ideal. It has been noted repeatedly that this conviction led to an ignorance of the persecution of partial interests. ${ }^{34}$ The untested celebration of private enterprise in world politics is repeating the same mistake. A renewed analysis of power structures is a debt to be discharged by political science; this, by the way, could also be a specific contribution of the discipline to the debate on transnational constitutionalism.

In spite of these critical remarks, though, a challenging question of societal constitutionalism ought to be taken up: how can the ways and means in which the state-centered world is built on its national constitutions be generalized and respecified in order to meet the empirical and normative needs of a fragmented and globalized world?

34. Renate Mayntz, Governance Theory als fortentwickelte Steuerungstheorie?, in GovernancEForschung. Vergewisserung über Stand und Entwicklungslinien 11 (Gunnar Folke Schuppert ed., 2005). 


\section{Indiana University Press/Journals}

"A cheeky journal of culture and politics."-New York Times

"The only decent forum for black intellectuals." - Village Voice

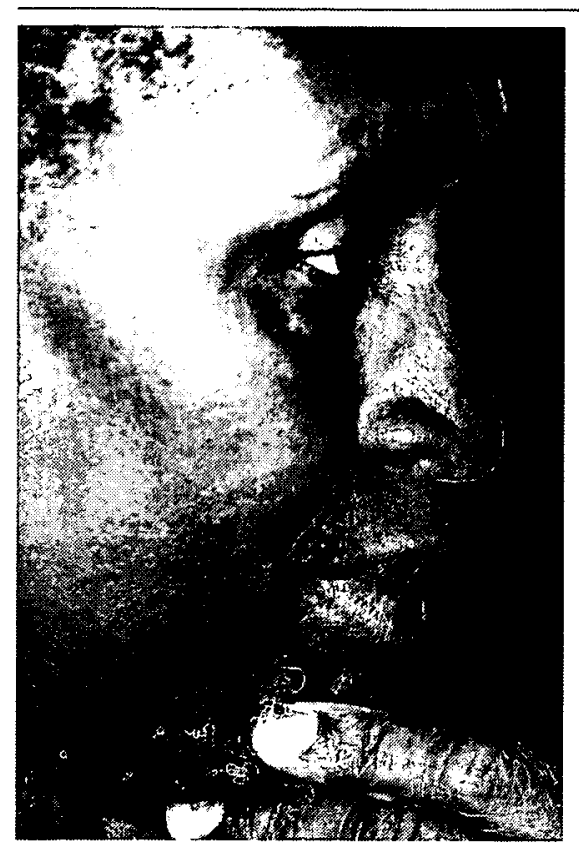

While other magazines routinely send journalists around the world, Transition invites the world to write back. Three times a year, its writers fill the magazine's pages with unusual dispatches, unforgettable memoirs, unorthodox polemics, unlikely conversations, and unsurpassed original fiction. A cosmopolitan journal with an emphasis on Africa and the diaspora, Transition tells complicated stories with elegant prose and beautiful images.

Contributors have included Janes Baldwin, Langston Hughes, Martin Luther King, Jr., Paul Theroux, Nadine Gordimer, Wole Soyinka, Jamaica Kincaid, Kofi Annan, Carlos Fuentes, Toni Morrison, Spike Lee, and Russell Banks. Essays from Transition have been reprinted in Best American Essays, The Beacon Best, Harpers, and the Utne Reader, while its fiction has been reprinted in Best American Short Stories and has been short-listed for the O'Henry Prize.

eISSN 1527-8042 pISSN 0041-1191

Transition is an international review of politics, culture, and ethnicity from Beijing to Bujumbura and is edited at the W.E.B. Du Bois Institute for African and African American Research at Harvard University.

800-842-6796/812-855-8817/hrtp://inscribe.iupress.org Available in electronic, combined electronic $\&$ print, and print formats

\section{TI $\mid \frac{\text { INDIANA UNIVERSITY PRESS }}{\text { INDIANA UNIVERITY }}$} 601 North Morton Street, Bloomington, Indiana 47404-3797 USA 